\title{
Resilience in trade fairs: a study in brazilian context
}

\author{
Resiliência em feiras livres: um estudo no contexto brasileiro
}

\section{Résilience en foires publiques: une étude dans le context bresilien}

\author{
Resiliencia en los mercados callejeros: un estudio en el contexto brasileño \\ Felipe Gerhard ${ }^{1}$ \\ Verónica Peñaloza ${ }^{1}$
}

Recebido em 30/08/2017; revisado e aprovado em 20/12/2017; aceito em 27/12/2017

DOI: http://dx.doi.org/10.20435/inter.v19i4.1699

\begin{abstract}
This research aims to analyze through the lenses of resilience, the collective construction and social representation of a trade fair by its actors. To this, an exploratory qualitative case study was conducted with vendors of a large trade fair in the city of Fortaleza. The main reasons that provide growth, reduction or stability of these environments are not restricted to purely financial factors; the resilience of trade fairs transcends a marketing perspective, achieving also social and cultural dimensions.

Keywords: resilience; trade fairs; social representation.

Resumo: Esta pesquisa objetiva analisar, através das lentes da resiliência, a construção coletiva e a representação de uma feira livre pelos seus atores. Para tal, um estudo exploratório de caráter qualitativo foi realizado com os feirantes de uma grande feira livre da cidade de Fortaleza. As principais razões que promovem o seu crescimento, redução ou estabilidade não se restringem a fatores exclusivamente financeiros; a resiliência das feiras livres transcende a perspectiva mercadológica, alcançando também dimensões sociais e culturais.
\end{abstract}

Palavras-chave: resiliência; feiras livres; representações sociais.

Resumé: Cette recherche vise à analyser, à travers la lentille de la résilience, la construction collective et la représentation d'une foire publique par ses acteurs. En effet, une étude exploratoire de caractère qualitatif a été réalisée avec les vendeurs d'une grande foire de la ville de Fortaleza. Les principales raisons qui favorisent sa croissance, réduction ou stabilité ne se limitent pas exclusivement aux facteurs financier. La résilience de ces marchés transcende la perspective du domaine mercadologique, dont les dimensions sociales et culturelles sont obtenu par laquelle.

Mots-clés: résilience; foires publiques; représentations sociales.

Resumen: Esta investigación tiene como objetivo analizar, desde la perspectiva de la resiliencia, la construcción colectiva y la representación de una feria que hacen sus actores. Con este fin, se llevó a cabo un estudio exploratorio, de carácter cualitativo, con los vendedores de una gran feria libre de la ciudad de Fortaleza. Los resultados indican que las principales razones que promueven su crecimiento, reducción o estabilidad no se limitan a factores puramente financieros; la resiliencia de las libres trasciende la perspectiva mercadológica, alcanzando también, dimensiones sociales y culturales.

Palabras clave: resiliencia; mercados callejeros; representaciones sociales.

\section{INTRODUCTION}

Due to the interconnection in terms of society, economy and technology, no element, organization or system might survive adversity and change or retain a competitive position as an independent entity (MEDD; MARVIN, 2005; BHAMRA; DANI; BURNARD, 2011; BURNARD; BHAMRA, 2011). In order to maintain competitive advantage, change and adaptation are required from current systems as a compulsory movement in response to environmental fluctuations (BURNARD; BHAMRA, 2011). Thus, resilience, given the adversities that cause deleterious development cycles entailed by environmental turbulences, is the corn stone for all agents present in market;

\footnotetext{
${ }^{1}$ Universidade Estadual do Ceará, Fortaleza, Ceará, Brasil.
} 
inasmuch it is characterized as a mechanism capable of habilitating individuals, organizations and systems to adapt to new risks accrued from the external environment (BURNARD; BHAMRA, 2011; OZUDURU; VAROL; ERSCOSKUN, 2012; PETRESCU; BHATLI, 2013).

Over the last decades, researches focused on further analysis of resilience have been gaining notoriety, both in academic field and in public policies (BURNARD; BHAMRA, 2011; OZUDURU; VAROL; ERSCOSKUN, 2012; SOUMAGNE et al., 2009). The concept of resilience, originated from natural sciences, has undergone theoretical adaptations to encompass an increasingly research scope. Although it has gained greater proportions especially in medical and behavioral sciences (SMITH et al., 2008), the concept could transit in diverse areas, helping disciplines and institutions to address their theoretical and practical problems.

Fast changes have been occurring in the socioeconomic context, requiring a restructuration of both formal and informal urban economic systems (BURNARD; BHAMRA, 2011). There is, however, greater vulnerability related to informal markets because they do not have at hand the same financial power or marketing amplitude achieved by the formal sector (OZUDURU; VAROL; ERSCOSKUN, 2012). Understanding the vulnerabilities and, consequently, the strengths that allow those economic systems to survive, would help to construct the idea of resilience.

Even though the researches in formal sectors have intensified over the past few years, the frequency of academic studies concerned with informal markets has not demonstrated the same growth (RAJAGOPAL, 2010; PETRESCU; BHATLI, 2013). Moreover, it is possible to assert that the theoretical framework versed in resilience is still insipid (RAJAGOPAL, 2010; PETRESCU; BHATLI, 2013; OZUDURU; VAROL; ERSCOSKUN, 2012).

Trade fairs, examples of informal retail systems, are as ancient as the first societies. Registers of their appearance date back to the first human groupings (PANDOLFO, 1987). Although they currently represent an opportunity to illegal markets (e.g., counterfeit and stolen products), trade fairs contribute to the lateral cycle of reuse of second hand items, reason why they also have received the denomination of alternative markets (BELK; SHERRY; WALLENDORF, 1988; SHERRY, 1990b). Moreover, they also are characterized by their low prices, product variety, social interactions, bargain and exciting buying experiences (BELK; SHERRY; WALLENDORF, 1988; SHERRY, 1990a; RAJAGOPAL, 2010). The importance of resilience in informal retail systems is centered on the capacity of those markets to adapt to the advances of formal sector, which has the image of shopping malls as its main exponent. Hence, informal markets find different solutions to avoid bankruptcy announced by the evolution of modern consumption centers (OZUDURU; VAROL; ERSCOSKUN, 2012).

Therefore, in view of the multitude of studies related to restructuring of formal markets and the lack of deeper conceptual contributions concerning the resilience of informal retail systems (OZUDURU; VAROL; ERSCOSKUN, 2012; PETRESCU; BHATLI, 2013), this research aims to analyze the resilience of those markets, represented here by a trade fair. Thus, the central purpose is to examine, through the lenses of resilience, the collective construction of trade fair's social representations by its own actors; raising, moreover, its vulnerabilities and strengths to verify how they help and, eventually, jeopardize the resilience of these environments.

This study is divided into four sections besides this introduction. Initially, it raises the main theoretical aspects related to trade fairs and the relation between resilience and economic systems. Next, it addresses the methodological questions, highlighting the research strategies and techniques that enable the achievement of the objectives. Posteriorly, it presents the most 
important research results. In the final section, it shows the study conclusions, as well as its limitations and suggestions for future researches.

\section{TRADE FAIRS}

There are trade fairs worldwide. Given that they ensure access to a great variety of cheap products, trade fairs are more strongly present in the quotidian of the poorest people (SHERRY, 1990b). Besides constituting the daily reality of people and cities, trade fairs were of fundamental importance to the birth of the first settlements. As they played an indispensable role in the development of commercial relations within and between different localities, trade fairs are pointed out as important elements responsible for transforming the first human groups in large urban centers (PIRENNE, 2014).

However, it is noteworthy that, though the trade fairs had been developed along with the first cities, an inverse process took place from the mid-twentieth century. In that time, the dynamics of market formalization phenomenon relegated the trade fairs to rural regions or poor areas in large urban centers (PANDOLFO, 1987; OLAVARRIETA et al., 2008; RAJAGOPAL, 2010). As a result of that process, trade fairs have received the denomination of functional anachronisms, as they usually are characterized as old fashion markets in an age of modern consumption temples (SHERMAN; MCCROHAN; SMITH, 1985; SHERRY, 1990a).

Even though they once represented the only commercial places available to local people, trade fairs have been disputing space with sumptuous consumption centers in the current urban centers. Although this is a traditional mercantile practice in emergent and sub-industrialized countries, trade fairs continue to defy modern economy, as they are able to develop at the same time with other commercial platforms, as warehouses, stores, supermarkets, and malls. Trade fairs are also characterized by the lack of governmental regulation and low entry barriers, as they do not require a high capital to install a new business, they operate in small scale, and, generally, they make intensive use of family labor (OLAVARRIETA et al., 2008; BUSSO, 2011).

According to Belk, Sherry and Wallendorf (1988) and Sherry (1990a; 1990b), the interactions developed in trade fairs transcend the cold unilateral relations of buying and selling present in formal markets. Such interactions are expanded in those places. The consumer, therefore, is free to negotiate, swap, and bargain desired products. Likewise, besides variety and products at affordable prices, the consumers are attracted by less utilitarian attributes such as fun, pleasure, friendship and excitement. Furthermore, Rajagopal (2010) highlights the ethnic element as the reason to attend trade fairs. According to the author, such environments preserve the historical roots of the visitors, which can be proven by the large number of regional typical products exposed, such as food, beverages, songs and the ambience musicality, specific products of a particular culture, among others.

Trade fairs are depicted as a fantastic economy (STEWART, 1982), as they do not follow the rules and principles that orientate the pragmatism of formal markets. They create, instead, their own value system, in spite of the hegemony of the current economic system. The cultural diversity, the strong social interaction and the human contact between consumers and vendors are factors that differentiate the fairs from the sober formal sector (MOLINA, 2009). It should be noted, however, that despite the fact trade fairs are present in the most diversified cultures and represent an alternative marketing view on formal markets, they have not been object of much reflection by academic researches. 


\section{CONCEPTUAL FRAMEWORK OF RESILIENCE}

Nevertheless the absence of a universal definition that meets the requirements of different sciences, the concept of resilience is essentially constant among the study fields (SIMMIE; MARTIN, 2010; BHAMRA; DANI; BURNARD, 2011), referring, in general, to an element's capacity of returning to or remaining in a stable state after a disruptive event.

In Table 1, a set of concepts about resilience is presented, with sciences in order of time when they first approached it.

Table 1 - Definitions of resilience

\begin{tabular}{|c|c|c|c|}
\hline Authors & Context & Definitions & Proprieties \\
\hline $\begin{array}{l}\text { Hollnagel, } \\
\text { Woods, and } \\
\text { Leveson (2006) }\end{array}$ & Engineering & $\begin{array}{l}\text { The ability to sense, recognise, adapt and absorb } \\
\text { variations, changes, disturbances, disruptions and } \\
\text { surprises }\end{array}$ & $\begin{array}{l}\text { Recognise; } \\
\text { Adapt; } \\
\text { Absorb }\end{array}$ \\
\hline Holling (1973) & $\begin{array}{l}\text { Ecological } \\
\text { Systems }\end{array}$ & $\begin{array}{l}\text { The measure of the persistence of systems and } \\
\text { of the ability to absorb change and disturbance } \\
\text { and still maintain the same relationships between } \\
\text { state variables }\end{array}$ & $\begin{array}{l}\text { Persist; } \\
\text { Absorb; } \\
\text { Maintain }\end{array}$ \\
\hline $\begin{array}{l}\text { Walker et al. } \\
\text { (2004) }\end{array}$ & $\begin{array}{l}\text { Socio-Ecological } \\
\text { Systems }\end{array}$ & $\begin{array}{l}\text { The capacity of a system to absorb a disturbance } \\
\text { and reorganise while undergoing change while } \\
\text { retaining the same function, structure, identity } \\
\text { and feedback }\end{array}$ & $\begin{array}{l}\text { Absorb; } \\
\text { Reorganize; } \\
\text { Retain }\end{array}$ \\
\hline $\begin{array}{l}\text { Carpenter et al. } \\
\text { (2001) }\end{array}$ & $\begin{array}{l}\text { Socio-Ecological } \\
\text { Systems }\end{array}$ & $\begin{array}{l}\text { The magnitude of disturbance that a system can } \\
\text { tolerate before it transitions into a different state } \\
\text { that is controlled by a different set of processes }\end{array}$ & Tolerate \\
\hline Rutter (2006) & Psychology & $\begin{array}{l}\text { Resilience is an interactive concept that refers } \\
\text { to a relative resistance to environmental risk } \\
\text { experiences, or the overcoming of stress or } \\
\text { adversity }\end{array}$ & $\begin{array}{l}\text { Resist; } \\
\text { Overcome }\end{array}$ \\
\hline $\begin{array}{l}\text { Herrman et al. } \\
\text { (2011) }\end{array}$ & Psychology & $\begin{array}{l}\text { Resilience is understood as referring to positive } \\
\text { adaptation, or the ability to maintain or regain } \\
\text { mental health, despite experiencing adversity }\end{array}$ & $\begin{array}{l}\text { Adapt; } \\
\text { Maintain; } \\
\text { Regain }\end{array}$ \\
\hline McDonald (2006) & Organisational & $\begin{array}{l}\text { Resilience conveys the properties of being able } \\
\text { to adapt to the requirements of the environment } \\
\text { and being able to manage the environments } \\
\text { variability }\end{array}$ & $\begin{array}{l}\text { Adapt; } \\
\text { Manage }\end{array}$ \\
\hline $\begin{array}{l}\text { Burnard and } \\
\text { Bhamra (2011) }\end{array}$ & $\begin{array}{l}\text { Organisational } \\
\text { Systems }\end{array}$ & $\begin{array}{l}\text { Resilience is the emergent property of } \\
\text { organisational systems that relates to the inherent } \\
\text { and adaptive qualities and capabilities that } \\
\text { enable an organisation adaptive capacity during } \\
\text { turbulent periods. }\end{array}$ & Adapt; \\
\hline $\begin{array}{l}\text { Briguglio et al. } \\
\text { (2009) }\end{array}$ & $\begin{array}{l}\text { Economic } \\
\text { Systems }\end{array}$ & $\begin{array}{l}\text { The policy-induced ability of an economy to } \\
\text { withstand or recover from the effects of such } \\
\text { shocks }\end{array}$ & $\begin{array}{l}\text { Withstand; } \\
\text { Recover }\end{array}$ \\
\hline $\begin{array}{l}\text { Soumagne et al. } \\
\text { (2009) }\end{array}$ & Urban Retail & $\begin{array}{l}\text { Capacity to regenerate the commercial urban } \\
\text { tissue of a pole, a neighbourhood, a centre. This } \\
\text { regeneration, however, on several material and } \\
\text { human facets of commerce and on attractiveness } \\
\text { in terms of costumers and distance from } \\
\text { residence and workplace vis-à-vis a specific pole. }\end{array}$ & Regenerate \\
\hline
\end{tabular}

Souce: Prepared by the authors. 
In general, independently of the object into analysis, whether an individual, an ecosystem or a social system, there are reiterated characteristics concerning to resilience among them. Resilience is frequently described as a capacity or a process, whose main properties are: Adaptation, retrieving, and resistance. Similarly, resilience provides other important properties as overcoming, learning, development and renovation. These actions, moreover, represent resilience capacities against disruptive variables as change, vulnerability, adversity, and stress.

\section{RESILIENCE IN RETAIL SYSTEMS}

Regarding the characteristics of resilience in economic systems, Ponomarov and Holcomb (2009) compare them with some aspects related to resilience of individuals. The authors elicit the following psychological properties as necessary elements to resilience: readiness and preparation; response and adaptation; recuperation and adjustment. Similarly, Keong and Mei (2010) point out four important traits of individual resilience in organizations, they are: flexibility, motivation, perseverance and optimism. Although economic systems take ownership of these traits and elements, the properties of resilience are not limited to them. The interconnection among the plurality of agents that compound this environment changes the process of resilience, as it gives rises to the development of emerging factors that are not present at individual level (BHAMRA; DANI; BURNARD, 2011; BURNARD; BHAMRA, 2011).

Emerging factors play an important role in exposing the vulnerabilities of a system, as they put their qualities to test. Vulnerability, defined as the degree to which the system is likely to experience difficulty due to exposure to threats and disturbances, is a concept invariably present in contexts of economic systems (HOLLING, 2001; BHAMRA; DANI; BURNARD, 2011). Likewise, in order to overcome the adversities incurred in the process of development of retail systems, it is also necessary the awareness of their own strengths. The comprehension and development of its own capabilities and competitive advantages enable the system to reach a privileged market position. In consequence, resilience actions as adaptation, maintenance, recovery and growth are expected to occur (HOLLING, 2001; BHAMRA; DANI; BURNARD, 2011; FRANCIS; BEKERA, 2014).

Whereas in Psychology the actions to crystallize the individual resilience are generally directed towards the enlargement of the social sphere, intensification of family ties, and selfknowledge, the literature of resilience in retail systems reveals homogeneity regarding the main dimensions responsible to increase the potentialities of systems with different social, cultural, and public policy aspects. Maintaining a certain parallelism with Psychology, the resilience in retail systems reveals a governmental, a systemic, and an individual level (Table 2).

Table 2 - Levels and measures for resilience crystallization in retail systems

- Modify positively the image of the environment

- Improve local access roads

- Intensify local security

- Expansion and structural reform (e.g., sidewalks, internal space, parking, stands)

Governmental Level

- Improve hygiene conditions

- Promote financial and business education

- Tourism expansion

- Limit the insertion of large enterprises nearby 


\begin{tabular}{ll}
\hline & - Economic growth and diversity \\
- Highlight cultural values, entertainment, and leisure \\
- Long-term planning \\
- Strong and responsible leadership \\
- Creation and divulgation of festivals \\
- Aesthetical concern \\
- Learning \\
- Establish solid interpersonal relationships with customers and \\
- Vompetitors \\
- Value strengths and competitive advantages \\
Individual Level & folders with products) \\
& - Self-organization \\
& Focus on innovation \\
\hline
\end{tabular}

Source: Adapted from Medd and Marvin (2005), Soumagne et al. (2009), Ozuduru, Varol, and Erscoskun (2012), Petrescu and Bhatli (2013), and Erkip, Kizilgün and Akinci (2014).

Although the rapport between dynamic capabilities and resilience have never been analysed before, both concepts are strongly related. Observing one of the first definitions of dynamic capabilities, formulated by Teece, Pisano, and Shuen (1997, p. 8), it is possible to realize a close relation with the definition of resilience: "We define dynamic capabilities as the firm's ability to integrate, build and reconfigure intimal and external competences to address rapidly changing environments". This concept expresses a highly similar idea in comparison to that obtained from the perspective of resilience.

In fact, resilience can be encompassed within the concept of dynamic capabilities. Abilities of adaptation, coordination, and reorganization are shared by both concepts, however, dynamic capabilities are beyond that, involving much more functions (AUGIER; TEECE, 2009). These elements are among several others present in a system's dynamic capabilities. Therefore, being resilient means to develop specific abilities related to dynamic capabilities, ranging from its cognitive microfoundations (HELFAT; PETERAF, 2015) to the adaptation of variations in the entire environment. In contrast, in dynamic capabilities perspective the system is also concerned with achieving and renewing competitive advantages in order to exploit specific internal and external system's capabilities to address changes in the environment. More precisely, resilience is concerned with the internal system process, whereas the dynamic capability theory is related to the whole environment.

\section{METHODOLOGY}

In order to achieve the proposed objectives, an exploratory research was carried out with vendors of a large trade fair located in the city of Fortaleza, the biggest city of Brazilian Northeast - the poorest region of the country. Moreover, the study is classified as qualitative, as the technique used in this research was the natural semantic network. According to Pericas (2005) , through this technique it is possible to draw a network-shaped graphic representation to promote the treatment of a large amount of data. The general objective of the semantic network is to emerge the social representation and the interactions among the main categories present at a specific phenomenon. Thus, a network representation is designed to reveal the central and peripheral aspects that emerged either by theory or research field (PERICAS, 2005). 
Regarding to the data analysis, we initially solicited the interviewees to answer, based on their own opinion, if the trade fair has grown, decreased, or remained constant over the last years. Similarly, we also inquired the vendors whether the projection of the Birds' Fair to the next years will grow, decrease, or remain stable. It is important to highlight that the questions were not restrained to economic aspects; in order to evoke personal impressions of the vendors, a short structured interview was used to approach the subjects. Thus, the interviews lasted approximately eight minutes in average. Subsequently, we requested the main reasons by which the vendors pointed out these future scenarios. Then, these reasons were classified in groups based on a close meaning. The words and expressions that did not reveal a semantic proximity to any group were excluded. Our research corpus comprised 232 vendors an consumers of Birds' Fair. Nevertheless, the researchers did not make distinction between formal or informal vendors. Moreover, we also interviewed consumers who often attend the trade fair in order to make commercial trades.

Concerning the calculation of the semantic distance, i.e. the relationship between the evoked word and the guiding question, we used the FMG method in order to instil more accurately the creation of a semantic network (VALDEZ, 1998). Initially, the method consists in assessing the $J$ value, obtained through the collection of all different defining words generated by the subjects. This parameter represents the semantic richness of the network. Then the $M$ value is obtained by multiplying the appearance frequency by the hierarchy of each defining word. This value represents an indicator of the semantic weight assessed to each semantic unit. Next, it is created the SAM set, i.e. the set of the 15 defining words with the higher M values. Lastly, the FMG value is calculated taking as a start point the defining word with the higher $M$ value. After working the data, the construction of the graphic is initiated by inserting the main defining groups found and their respective semantic distance from the core (NOVAK; CAÑAS, 2008).

The relevance of the research environment also needs to be emphasized. Birds' Fair is one of the main popular commercial centres of Fortaleza. Situated at the edge of a large lagoon, the trade fair has been trading a plurality of products for over 20 years at the same place. There is a permanent supply of every kind of stuff, from food and clothing to scrap, electronics, cars and animals. Its name, moreover, is due to the commercialization of wild birds, a common illegal practice at the place (MENEZES, 2005).

Although there is a formal register of the sellers that work in the trade fair (2,187 in 2009), the city hall asserts its unawareness of the actual number of informal vendors working at the Birds' Fair today (2017). Informality, combined with illegal aspects, is the dominant structure of the trade fair, as no taxes are paid by the sale of goods. Moreover, it is important to highlight the current context that the Birds' Fair is going through. Over the last three years, two large shopping malls were inaugurated around the trade fair. More specifically, the constructions are about two kilometres from it. Therefore, the trade fair faces a serious market threat able to weaken the flow of customers and, hence, the sales volume.

\section{THE SOCIAL, ECONOMIC, AND CULTURAL DYNAMICS OF THE TRADE FAIR}

Aiming to achieve the research goals, initially the researchers asked the vendors of the trade fair whether they believe the Birds' Fair has been growing, diminishing, or remaining constant over the last years. 165 (71.1\%) out of 231 responses pointed out that the trade fair has grown 
over the last years, against $19(8.2 \%)$ that indicated decrease and 48 (20.7\%) that did not notice any change in the trade fair. The results indicate that the trade fair, based on the opinion of its own vendors, is characterized as a resilient market. Likewise, the vendors were also inquired what would be the projection for the next years. Among the 232 responses, 139 (59.9\%) interviewees believe that the Birds' Fair will grow, whereas only 25 (10.8\%) indicate that the trade fair will diminish and 68 (28.3\%) believe in a stable future. Even though the ratio is somewhat smaller than the one found about the last years, the vendors also believe in a resilient future.

As for the descriptive data of the respondents, 96 (41.4\%) are female and 136 (58.6\%) are male, mean age of about 44 years and 12,7 years of work at the Birds' Fair. Moreover, the income informed by the vendors is around 1.5 of the monthly minimum wage (approximately $\$ 250$ by the reference year of the research).

Consequently, we initiated the necessary procedures for the creation of the trade fair's semantic network. Among a total of 414 words or expressions, the vendors mentioned 264 different semantic units. They were classified into 19 defining groups according to the semantic similarity of the words. It is important to highlight that 45 words or expressions were not grouped, as they did not present semantic similarity with the raised groups. Moreover, these semantic units, in general, do not represented significant contribution to the analysis, e.g., "because it is", "it will not change", "because it is better", "it cannot get worse"; "the rain would improve the production", "system" etc. The formed groups are presented in Table 3 below.

Table 3 - Defining groups, J and $M$ values, and main expressions

\begin{tabular}{|c|c|c|c|}
\hline Defining Groups & J Value & M Value & Main Words and Expressions \\
\hline Population Growth & 19 & 68 & $\begin{array}{c}\text { Population is increasing; Increasing of population; } \\
\text { Population growth }\end{array}$ \\
\hline Competitiveness & 19 & 59 & $\begin{array}{c}\text { Competitiveness; Supermarkets; Shopping malls; } \\
\text { Imported products }\end{array}$ \\
\hline $\begin{array}{l}\text { Current National } \\
\text { Conjecture }\end{array}$ & 16 & 49 & $\begin{array}{c}\text { Development; National Economy; Increase of income of } \\
\text { low income classes }\end{array}$ \\
\hline Unemployment & 68 & 243 & $\begin{array}{l}\text { Unemployment; Difficulty in obtaining employment; } \\
\text { Lack of job }\end{array}$ \\
\hline Entrepreneurship & 28 & 91 & $\begin{array}{c}\text { Financial independence; Own business; Individual } \\
\text { entrepreneur program }\end{array}$ \\
\hline Spatial Limitation & 42 & 159 & $\begin{array}{l}\text { Space; Crowded space; Lack of space; Lack of space to } \\
\text { growth }\end{array}$ \\
\hline Lack of Infrastructure & 8 & 26 & $\begin{array}{l}\text { Lack of infrastructure; Lack of bathrooms; Lack of } \\
\text { organization }\end{array}$ \\
\hline Positive Image & 10 & 26 & $\begin{array}{c}\text { People likes trade fair; Well seen; Very well-known; Very } \\
\text { popular }\end{array}$ \\
\hline Insecurity & 12 & 37 & Insecurity; Thief; Lack of security; Violence \\
\hline $\begin{array}{l}\text { Labour and Income } \\
\text { Opportunity }\end{array}$ & 30 & 86 & $\begin{array}{c}\text { Opportunity of job; Source of income; Opportunity to } \\
\text { earn the own money }\end{array}$ \\
\hline Public Policies & 19 & 63 & $\begin{array}{c}\text { Government; Lack of politic interest; Lack of } \\
\text { investment; Public oversight }\end{array}$ \\
\hline Tradition & 7 & 14 & Tradition; Historic; Traditional \\
\hline Trade Fair Transfer & 5 & 16 & $\begin{array}{l}\text { The trade fair will end up; The trade fair will be } \\
\text { removed; Due to the trade fair transfer }\end{array}$ \\
\hline Tourism and Leisure & 9 & 27 & Tourism; Open on Sundays; Day off; Hobby \\
\hline Variety and Novelty & 5 & 16 & Quantity of products; Search for variety; Novelty \\
\hline
\end{tabular}

Source: Prepared by the authors. 
Many reasons were pointed out as responsible by the growth, maintenance or decrease of the trade fair. The reasons are not restricted exclusively to financial factors, e.g., quantity of clients or sales volume. According to the vendors' view, the dynamic of the trade fair is related to a wide range of factors, as marketing, spatial, social, and even cultural aspects. The results indicate concerns that transcend the mere economic dimension of the trade fair. Factors related to the social and cultural dimensions are highlighted in the discourse of some vendors. Their speech is based on intangible values that are dissonant from the traditional economic rationalism (STEWART, 1982; RAJAGOPAL, 2010). The Birds' Fair plays an important social role by providing employment and income while it also provides, besides a conventional place of purchase at low prices, an ambience of leisure and fun.

Expressions such as "very popular", "tradition", "historic", and "people like the fair" demonstrate a possible insertion of this place in the collective consciousness of society. This is due to the different and unique properties of the trade fair in comparison to those found in other markets. Cold buying and selling relationships, common in the usual markets, are expanded at the trade fair. "The customer does what he/she wants", as expressed by one of the vendors, reveals the freedom of action of the passers-by. This aspect amplifies the interactions between vendors and consumers, incurring, at times, friendship among them. Trading, bargaining and negotiating are parallel forms of commercialization that assist the attainment of mercantile aims in the trade fair (SHERRY, 1990a; 1900b; RAJAGOPAL, 2010).

Likewise, the respondents highlighted the festive dimension of the trade fair. Corroborating the theoretical conceptions emerged by Sherry (1990a; 1990b), Rajagopal (2010), and Peñaloza et al. (2015), terms like "rich people have the hobby of coming to the trade fair", "it is not a trade fair anymore but a leisure pole", "have fun", "search for leisure", were repeatedly mentioned. Therefore, these considerations confirm the transcendent aspect of the trade fair. The hedonic dimension is present and active in the ambience, influencing interactions and relations among consumers, vendors and the trade fair itself (SHERRY, 1990a; 1990b; RAJAGOPAL, 2010; PEÑALOZA et al., 2015).

In spite of its hedonic dimension, it is important to highlight the essential economic role developed by the trade fair. It also means for its actors a source of employment and income and, consequently, the survival of a large number of workers excluded from the formal labour market. Hence, the trade fair also has an important social role, as it hosts a large contingent of unemployed workers that take from their stalls the income necessary to survive another week. Expressions like "lack of qualification", "difficulty of employment for people over 40" and "lack of jobs" reveal both the desperation of the vendors in face of unemployment and the opportunity of a labour resumption. Furthermore, the trade fair represents the liberation of employers' bonds for its vendors, as the choice of informal work is an alternative against the salaried life prison. Terms as "having no boss", "informal work", and "paying my own wage" translate the image of the trade fair into a redeeming locus capable to release them from the oppressive employment bond of the formal market.

Expressions related to personal characteristics of the vendors or properties of the trade fair are also exposed. As the ambience is composed by a complex confluence of social agents, different psychological and marketing aspects are raised among the answers. Semantic units as "the trade fair will adapt", "there will be more clients", "the sales will increase, God willing", "Lord help us", and "this trade fair is blessed" denote fundamental attributes to individual and marketing resilience as growth, adaptation, response capacity, perseverance and optimism (PONOMAROV; HOLCOMB, 2009; KEONG; MEI, 2010; ERKIP; KIZILGÜN; AKINCI, 2014). A religious 
aspect is highlighted among the vendors that mix optimism and faith in God to develop a high psychological resilience. Moreover, a vendor even added: "If we don't believe that things will get better, we ought to pray".

Consequently, we developed the semantic network through the creation of the SAM set (15 main defining groups with the higher $M$ values). Some semantic groups, as "quantity of customers" and "increase in the quantity of vendors", were removed once they do not bring contributions to the analysis and the insertion of those groups probably will entail an analysis of the causes by their own effects. After the data analysis, a semantic network was built (Figure 1). The defining groups with a semantic power above $50 \%$ in relation to the main group were classified as essential attributes; those among $30 \%$ and $50 \%$ were classified as secondary attributes; those among $20 \%$ and $30 \%$ as peripheral attributes; and finally, the groups with the smaller semantic powers, below 20\%, were defined as individual meanings. Furthermore, the defining groups were divided among those that represent strengths of the trade fair - as they permit its growth or stability - and those that denote vulnerability - as they hinder its resilience.

Figure 1 - Semantic network of the trade fair

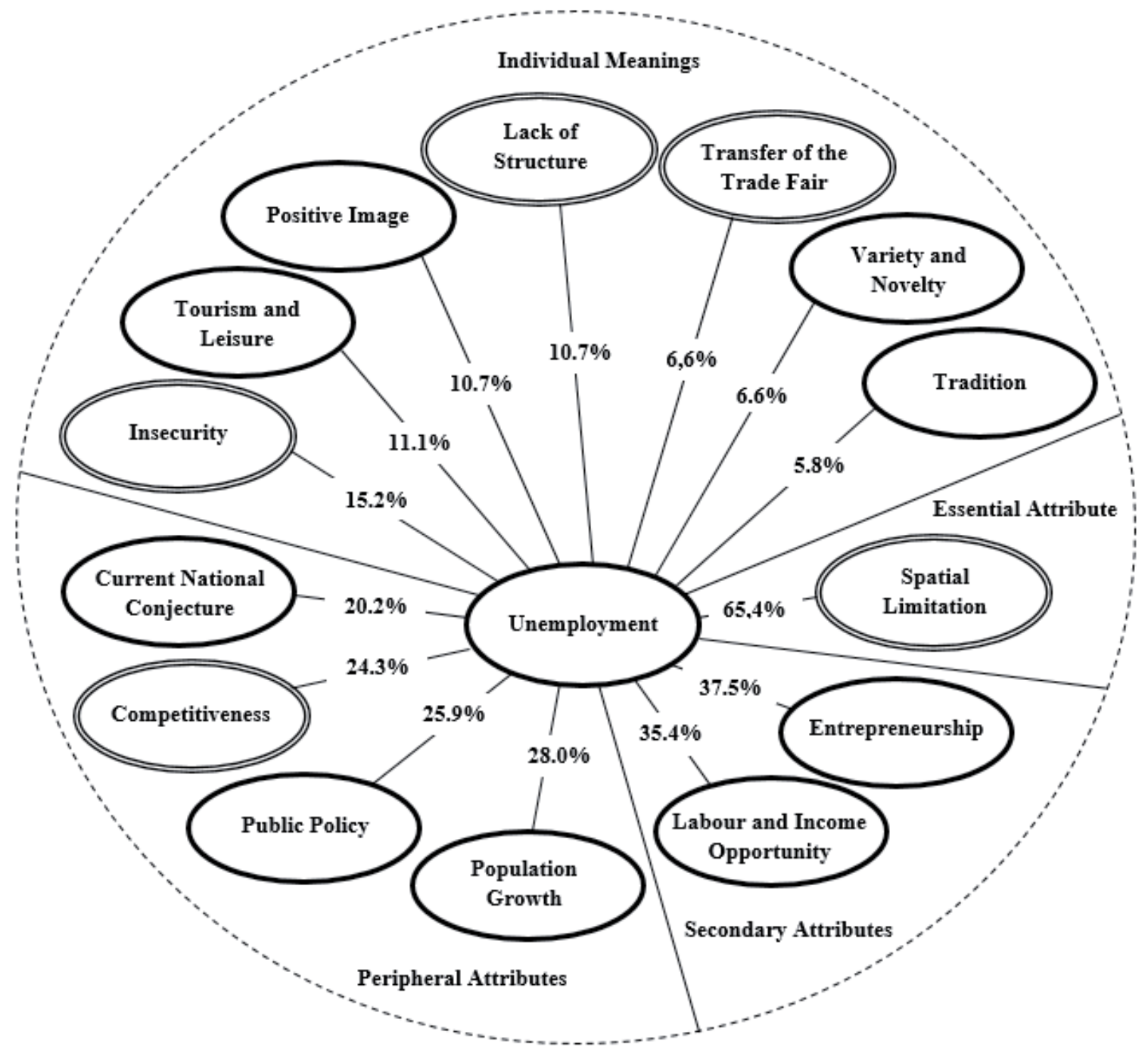

Notes: Reasons that facilitate the growth or stability of the trade fair. Reasons that hamper the growth or stability of the trade fair.

Source: Own authorship. 
The main defining group of the resilience in the Birds' Fair is the unemployment. This set enables the growth of vendors and, consequently, the offer of products present at the trade fair, as it represents an opportunity to restart in the labour field. The importance attributed to this factor ratifies the fundamental social role performed by the trade fair. According to the United Nations (UNITED NATIONS HUMAN SETTLEMENTS PROGRAMME [UN-Habitat], 2012), the city of Fortaleza, where the Birds' Fair is located, is one of the most unequal in the world. Thus, despite the incipient formal sector, it represents an alternative market for local workforce to obtain its monthly income.

The essential attribute spatial limitation is the second factor with higher semantic power (65.4\%). The factor is an element that hinders the growth of the trade fair, jeopardizing the local resilience. The vendors indicated the spatial limitation as the main vulnerability of the environment currently and for the next few years. Hence, a resilience condition presumes a coordinated development, once growth per se does not inhibit the vulnerabilities of an ambience. New vendors and hawkers arrange themselves along the short spaces of sidewalks and curbs, as well as at the margins of the lagoon.

Regarding the secondary attributes, all the factors represent important aspects that benefit the resilience of the trade fair. The vendors also pointed out the importance of the defining groups entrepreneurship (37.5\%) and labour and income opportunity (35.4\%) as responsible for the resilience of the trade fair. Along with unemployment, these semantic groups characterize particular socio-cultural aspects of Brazilian markets and labour force. Different from other social contexts, local vendors face trade fairs as the main source of income. Whereas in north countries they generally take on the designation of flea markets - involving, basically, the commerce of second-hand products and the exchange of antiquities (BELK; SHERRY; WALLENDORF, 1988; SHERRY, 1990b) -, in Brazil, trade fairs represent a broader social phenomenon. Gathering socio-cultural concerns within a market-based environment, trade fairs not only expose social vulnerabilities but also reveal the creativity of our people to struggle against economic restrains. Together, unemployment, entrepreneurship, and labour and income opportunity evidence how the economic realm is entangled with other ones in our local context, once it is permeated by activities anchored on a wider social-cultural ground.

The peripheral attributes population growth (28.8\%) and current national conjecture $(20.2 \%)$ are also pointed out as important defining groups that enable the crystallization of resilience in such environments. On the other hand, the factors competitiveness (24.3\%), related mainly to external agents, and public policy (25.9\%) hamper the resilience process. It is relevant to highlight the representational inversion of the public policy in the vision of the vendors. This factor presents a dysfunctional role once its function should be to support the development of the trade fair rather than to represent a threat to it. Retail urban systems are extremely dependent of public policies. They are responsible to improve the local access roads, to intensify the local security, to increase the hygiene conditions and infrastructure, to prohibit the insertion of large enterprises in the region, among others (MEDD; MARVIN, 2005; SOUMAGNE et al., 2009; KÄRRHOLM; NYLUND; FUENTE, 2014; OZUDURU; VAROL; ERCOSKUN, 2012; PETRESCU; BHATLI, 2013; ERKIP; KIZILGÜN; AKINCI, 2014).

Although the remaining attributes provide great exploratory power, their contributions are characterized as individual meanings as long as they do not represent generalized opinions but specific to certain vendor groups. Thus, insecurity (15.2\%), lack of structure (10.7\%), and transfer 
of the trade fair (6.6\%) are vulnerabilities present in the daily life of the trade fair, although their influences focus more strongly on specific groups. On the other hand, the attributes tourism and leisure (11.1\%), positive image (10.7\%), variety and novelty (6.6\%), and tradition (5.8\%) represent to the trade fair opportunities of growth. However, regarding positive attributes, any defining group emerged is caused by individual or systemic interventions. Actions such as long-term planning, leadership, creation and disclosure of events, aesthetic preoccupation, implementation of marketing strategies, spatial organization, among others, usually related to the capacities of the vendors themselves (OZUDURU; VAROL; ERCOSKUN, 2012; PETRESCU; BHATLI, 2013; ERKIP; KIZILGÜN; AKINCI, 2014), are not pointed out by the vendors as responsible by the resilience of the trade fair. Such consideration indicates an excessive dependence of external factors to its stability or development.

\section{CONCLUSIONS}

Guided by the objective of analysing the resilience of a trade fair, observing its collective construction and social representation of its own actors, this research obtained success. The vulnerabilities and strengths of a large Brazilian trade fair were emerged in order to reach the main aspects that assist or jeopardize the process of resilience in these markets. Through the analysis of the research findings, we note that the process of resilience is constituted by factors that transcend the traditional economic vision. The social and cultural perspectives, which are composed by intangible values that diverge from the classic economic rationalism, aid to construct the ambience of trade fairs. These markets resist because they represent to their vendors and customers, besides an opportunity to purchase a huge variety of products at low price, a stage where an almost unlimited multitude of social actors present their spectacles.

What contributes to this multiplicity of interactions is its important social role. The trade fair provides employment and income to a workforce willing to work that probably would not obtain an opportunity in formal market due to the lack of workplaces, labour disqualification, and advanced age. Likewise, the trade fair represents the freedom from patronal bonds as well as independence of employment and income. However, it is important to highlight that the vendors do not understand themselves as responsible for the development of the trade fair. Similarly, they cannot realize their own vulnerabilities and strengths in order to increase the local systemic resilience. This movement of reflexion is important to the learning dynamics and to expand the competitive capacity of the vendors. Learning with their own mistakes and limitations facilitates the suppression of external threats. Moreover, while the main qualities and resources are highlighted there is an increment of the dynamic capabilities.

Concerning the governmental actions, the results reveal a serious dysfunction of the public policies towards the trade fair. The presence of the government should represent an aspect to increment resilience but the vendors reveal the opposite. The governmental absence and its mistaken actions aggravate external competitiveness, insecurity, and harm the local infrastructure.

The trade fair competes with other markets, such as shopping malls, supermarkets, and even internet, once they commercialize similar products. However, while it faces a multilateral concurrence, the trade fair does not compete directly with neither of them. The trade fair adapts and grows because it offers to its customers some attributes that transcend the purely economic dimension. The reductionist and segregating financial logic, that orientates the formal markets, generates a sober distance between enterprises and customers. This relation is even more injured 
due to the mechanical behaviour of the salespersons, based on insipid perspectives of customer relationship. A necessary movement to formal enterprises is the introjection of sociocultural values, arising more casual and honest interactions with clients.

The trade fair is constituted by regular people. They do not wear uniform of large corporations, harming the interaction between vendors and customers. They play the role of vendors as they are in any time: Real people. In addition, the autonomy of the customer also contributes to increase the quality of the relationship between trade fair vendors and customers, frequently conducting them to friendship. The unilateral interaction of selling and buying is expanded in these ambiences, encompassing parallel forms of commercialization, as negotiation, bargain, and permutation. Indeed, the trade fair is also characterized as a singular economy, with a system of values that overpasses the pragmatism of formal markets. The strong social interaction and human contact between buyers and vendors, amid the cultural diversity and the profusion of regional ethnic values, represent competitive advantage for trade fairs.

As suggestion for future research, we point out the study of the contribution played by the cooperation strategy to the process of resilience. The mutual assistance among the trade fair actors increases important systemic capabilities as reorganization, reaction, and socioeconomic development. Likewise, due to the importance of the concept to the process of resilience, we suggest the research of the learning dynamics presented at the trade fair among its agents and through its generations.

\section{REFERENCES}

AUGIER, M.; TEECE, D. J. Dynamic capabilities and the role of managers in business strategy and economic performance. Organization Science, v. 20, n. 2, p. 410-21, 2009.

BELK, R.; SHERRY, J. Y.; WALLENDORF, M. A naturalistic inquiry into buyer and seller behavior at a Swap Meet. Journal of Consumer Research, v. 14, n. 4, p. 449-70, 1988.

BHAMRA, R.; DANI, K.; BURNARD, K. Resilience: the concept, a literature review and future directions. International Journal of Production Research, v. 49, n. 18, p. 5375-93, 2011.

BRIGUGLIO, L. et al. Economic vulnerability and resilience: concepts and measurements. Oxford Development Studies, v. 37, n. 3, p. 229-47, 2009.

BURNARD, K.; BHAMRA, R. Organisational resilience: development of a conceptual framework for organisational responses. International Journal of Production Research, v. 49, n. 18, p. 5581-99, 2011.

BUSSO, M. Las ferias comerciales: también un espacio de trabajo y socialización. Aportes para su estudio. Trabajo y Sociedad, Santiago del Estero, n. 16, p. 105-23, 2011.

CARPENTER, S. et al. From metaphor to measurement: resilience of what to what? Ecosystems, v. 4, n. 8, p. 765-81, 2001.

ERKIP, F.; KIZILGÜN, O.; AKINCI, G. M. Retailers' resilience strategies and their impacts on urban spaces in Turkey. Cities, v. 36, p. 112-20, 2014.

FRANCIS, R.; BEKERA, B. A Metric and frameworks for resilience analysis of engineered and infrastructure systems. Reliability Engineering and System Safety, v. 121, p. 90-103, 2014.

HELFAT, C. E.; PETERAF, M. A. Managerial cognitive capabilities and the microfoundations of dynamic capabilities. Strategic Management Journal, v. 36, n. 6, p. 831-50, 2015.

HERRMAN, H. et al. What is resilience? The Canadian Journal of Psychiatry, v. 56, n. 5, p. 258-65, 2011.

HOLLING, C. S. Understanding the complexity of economic, ecological, and social systems. Ecosystems, v. 4, n. 5, p. 390-405, 2001. 
Resilience and stability of ecological systems. Annual Review of Ecology and Systematics, v. 4, n. 1, p. 1-23, 1973.

HOLLNAGEL, E.; WOODS, D. D.; LEVESON, N. Resilience engineering: concepts and precepts. Aldershot: Ashgate, 2006.

KÄRRHOLM, M.; NYLUND, K.; FUENTE, P. P. Spatial resilience and urban planning: addressing the interdependence of urban retail areas. Cities, v. 36, p. 121-30, 2014.

KEONG, F. W. F.; MEI, L. Y. Sustainable development: the effect of adopting green technology on small and medium enterprises' (smes) business resilience and competitiveness. In: INTERNATIONAL CONFERENCE ON BUSINESS AND ECONOMIC RESEARCH, 1., 2010. Anais... Malaysia, 2010.

MCDONALD, N. Organisational resilience and industrial risk. In: HOLLNAGEL, E., WOODS, D. D.; LEVESON, N. (Ed.). Resilience engineering: concepts and precepts. Hampshire: Ashgate, 2006. p. 155-79.

MEDD, W.; MARVIN, S. From the politics of urgency to the governance of preparedness: a research agenda on urban vulnerability. Journal of Contingencies and Crisis Management, v. 13, n. 2, p. 44-9, 2005.

MENEZES, V. As feiras-livres em Fortaleza - retrato da polissemia urbana. 2005. 130f. Master Thesis in Geography, Universidade Estadual do Ceará, Fortaleza, 2005.

MOLINA, E. C. Aportes conceptuales sobre las prácticas sociales en la feria callejera. El tema de la confianza social. Polis - Revista Latinoamericana, n. 24, p. 2-12, 2009.

NOVAK, J.; CAÑAS, A. The theory underlying concept maps and how to construct and use them. Florida: Florida Institute for Human and Machine Cognition, 2008. Available at: <http://cmap.ihmc.us/Publications/ ResearchPapers/TheoryUnderlyingConceptMaps.pdf>.

OLAVARRIETA, S. et al. Un análisis a los atributos relevantes de los mercados de las pulgas para los compradores: evidencia desde América Latina. Revista de Ciencias Sociales, v. 14, n. 3, p. 468-78, 2008.

OZUDURU, B. H.; VAROL, C. Y.; ERCOSKUN, O. Y. Do shopping centers abate the resilience of shopping streets? The co-existence of both shopping venues in Ankara, Turkey. Cities, v. 36, p. 145-57, 2012.

PANDOLFO, M. Feira de São Cristovão: a reconstrução do nordestino num mundo de paraíbas e nortistas. 1987. 233f. Thesis (Master in Administration)- Fundação Getúlio Vargas, Rio de Janeiro, RJ, 1987.

PEÑALOZA, V. et al. Consumo en mercados alternativos para baja renta: un estudio de la Feria de ParangabaBrasil. Revista Latinoamericana Polis, v. 14, n. 41, p. 481-97, 2015.

PERICÁS, V. El uso de la teoría de redes sociales en la representación y análisis de textos. De las redes semánticas al análisis de redes textuales. EMPIRIA - Revista de Metodología de las Ciencias Sociales, n. 10, p. 129-50, 2005.

PETRESCU, M.; BHATLI, D. Consumer behavior in flea markets and marketing to the Bottom of the Pyramid. Journal of Management Research, v. 13, n. 1, p. 55-63, 2013.

PIRENNE, H. Medieval cities: their origins and the revival of trade. New Jersey: Princeton University Press, 2014.

PONOMAROV, S. Y.; HOLCOMB, M. C. Understanding the concept of supply chain resilience. The International Journal of Logistics Management, v. 20, n. 1, p. 124-43, 2009.

RAJAGOPAL. Coexistence and conflicts between shopping malls and street markets in growing cities: analysis of shoppers' behavior. Journal of Retail \& Leisure Property, v. 9, n. 4, p. 277-301, 2010.

RUTTER, M. Implications of resilience concepts for scientific understanding. Annals of the New York Academy of Sciences, v. 1094, n. 1, p. 1-12, 2006.

SHERMAN, E.; MCCROHAN, K. Y.; SMITH, J. D. Informal retailing: an analysis of products, attitudes, and expectations. Advances in Consumer Research, v. 12, n. 1, p. 204-08, 1985.

SHERRY, J. F. A Sociocultural Analysis of a Midwestern American Flea Market reviewed. Journal of Consumer Research, v. 17, n. 1, p. 13-30, 1990a. 
. Dealers and dealing in a periodic market: informal retailing in ethnographic perspective. Journal of retailing, v. 66, n. 2, p. 174-200, $1990 \mathrm{~b}$.

SIMMIE, J.; MARTIN, R. L. The economic resilience of regions: towards an evolutionary approach. Economy and Society, Cambridge Journal of Regions, v. 3, n. 1, p. 27-44, 2010.

SMITH, B. W. et al. The Brief Resilience Scale: assessing the Ability to Bounce Back. International Journal of Behavioral Medicine, v. 15, p. 194-200, 2008.

SOUMAGNE, A. et al. Retail planning for cities sustainability. DGALN/Plan Urbanisme Construction Architecture, Paris, 2009.

STEWART, S. On Longing: narratives of the miniature, the gigantic, the souvenir, the collection. Baltimore: Johns Hopkins University Press, 1982.

TEECE, D. J.; PISANO, G.; SHUEN, A. Dynamic capabilities and strategic management. Strategic Management Journal, v. 18, n. 7, p. 509-33, 1997.

UNITED NATIONS HUMAN SETTLEMENTS PROGRAMME (UN-HABITAT). State of the world's cities 2012/2013: prosperity of cities. London: Earthscan, 2012.

VALDEZ, J. Las redes semánticas Naturales: usos y aplicaciones en Psicología Social. México: Universidad Autónoma del Estado de México, 1998.

WALKER, B. et al. Resilience, adaptability and transformability in social ecological systems. Ecology and Society, v. 9, n. 2, p. 1-9, 2004.

\section{About the authors:}

Felipe Gerhard: PhD. student, Postgraduate Program of Administration at Universidade Estadual do Ceará. E-mail: gerhard.sousa@aluno.uece.br

Verónica Peñaloza: PhD. in Economics at Universidade de São Paulo. Professor, Postgraduate Program of Administration at Universidade Estadual do Ceará. E-mail: veronica.penaloza@uece.br 
